\title{
KEY PARAMETERS OF AUTOLOGOUS BIOMEDICAL PRODUCT FOR CARTILAGE TISSUE REPAIR
}

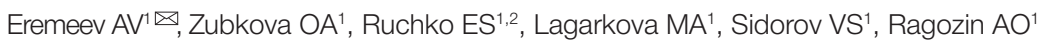

${ }^{1}$ Federal Research and Clinical Center of Physical and Chemical Medicine, FMBA, Moscow, Russia

${ }^{2}$ Moscow Timiryazev Agricultural Academy, Moscow, Russia

Repair of cartilage defects associated with injury or pathology is a clinically relevant problem. Chondral tissue, especially articular cartilages, has a poor regenerative potential. Inflammation triggers the growth of connective tissue, which cannot exert the normal function of the hyaline cartilage. This contributes to the progression of the pathology and eventually raises the need for surgery. At present, there are no pharmaceutical drugs capable of restoring the damaged cartilage. However, advances in cell-based technology hold promise for regenerative medicine. Reports describing fabrication of autologous cartilage transplants pose a special interest. A registration dossier of a biomedical cell product must contain the product's specifications, presenting the basic characteristics of the product that can be used to assess its quality. This review looks at a few basic parameters that can be used to verify the authenticity of the cell product derived from autologous chondrocytes and describe its specifications.

Keywords: chondrocytes, donor tissue, biomedicine, cell product, cell culture, biomarker expression

Funding: this work was part of the State Assignment for the Federal Research and Clinical Center of Physical and Chemical Medicine (2019-2020).

Acknowledgements: we thank Bogdanov AYu, quality assurance deputy director of Microgen Research and Production Association for his consultation on quality control in the production of biomedical cell products.

Author contribution: Eremeev AV — supervision; Zubkova OA — data acquisition; Ruchko ES — data acquisition, references; Lagarkova MA — editing; Sidorov VS - market analysis; Ragozin AO — analysis of published clinical studies.

$\square$ Correspondence should be addressed: Artyom V. Eremeev

Malaya Pirogovskaya, 1a, 119435, Moscow; art-eremeev@yandex.ru

Received: 02.09.2020 Accepted: 02.10.2020 Published online: 19.11.2020

DOI: $10.47183 /$ mes.2020.014

\section{КЛЮЧЕВЫЕ ХАРАКТЕРИСТИКИ АУТОЛОГИЧНОГО БИОМЕДИЦИНСКОГО ПРОДУКТА ДЛЯ КОРРЕКЦИИ ДЕФЕКТА ХРЯЩЕВОЙ ТКАНИ}

\author{
А. В. Еремеев ${ }^{1 凶}$, О. А. Зубкова ${ }^{1}$, Е. С. Ручко ${ }^{1,2}$, М. А. Лагарькова ${ }^{1}$, В. С. Сидоров ${ }^{1}$, А. О. Рагозин ${ }^{1}$ \\ 1 Федеральный научно-клинический центр физико-химической медицины Федерального медико-биологического агентства, Москва, Россия \\ ${ }^{2}$ Российский государственный аграрный университет — МСХА имени К. А. Тимирязева, Москва, Россия
}

Восстановление десектов хрящевой ткани после повреждений или при патологиях - одна из актуальных проблем в медицине. Физиологической и гистологической особенностями хрящевой ткани, особенно суставов, является пониженная способность к регенерации. Возникающее воспаление ведет к индукции образования соединительной ткани, которая уже не выполняет функции гиалинового хряща, что позволяет прогрессировать патологическому процессу и в итоге приводит к необходимости хирургического вмешательства. Фармацевтических препаратов, полностью востанавливающих поврежденную хрящевую ткань, на сегодняшний день на рынке нет. Между тем, большие надежды дает развитие клеточных технологий для нужд регенеративной медицины. В этой связи актуальны работы по созданию аутологичного хрящевого импланта для коррекции дефектов хрящевой ткани. При составлении регистрационного досье одним из основных документов является специсикация на биомедицинский клеточный продукт (БМКП). В ее основе лежит описание основных характеристик продукта, исходя из которых проводят контроль его качества. В настоящем обзоре представлен набор основных характеристик (показателей), которые можно использовать как для аутитентификации (процедуры проверки подлинности) разрабатываемого нами БМКП на основе аутологичных хондроцитов, так и для составления его спецификации.

Ключевые слова: хондроциты, донорский материал, биомедицина, клеточный продукт, культивирование клеток, экспрессия маркеров

Финансирование: работа выполнена в рамках Государственного задания ФГБУ ФНКЦ ФХМ ФМБА России на период 2019-2020 г.

Благодарности: авторы благодарят заместителя директора по качеству АО НПО «Микроген» А. Ю. Богданова за консультацию в области контроля качества при производстве биомедицинских клеточных продуктов.

Вклад авторов: А. В. Еремеев - общее руководство написания обзора; О. А. Зубкова - сбор информации; Е. С. Ручко - сбор информации, оформление списка литературы; М. А. Лагарькова - редактирование статьи; В. С. Сидоров - анализ рынка биомедицинских клеточных продуктов; А. О. Рагозин - анализ информации по клиническим испытаниям.

$\checkmark$ Для корреспонденции: Артём Валерьевич Еремеев ул. Малая Пироговская, д. 1а, 119435, г. Москва; art-eremeev@yandex.ru

Статья получена: 02.09.2020 Статья принята к печати: 02.10.2020 Опубликована онлайн: 19.11.2020

DOI: $10.47183 /$ mes.2020.014

Hyaline cartilage repair poses a significant challenge due to the complex microarchitecture, avascular nature and poor regenerative potential of articular cartilage tissue, especially in advanced-age patients. Today, it is recognized that this problem requires a multifaceted approach involving the use of cell-based technology, new materials, gene engineering, growth factors, hormones, and drugs [1, 2].

Articular cartilage repair after an injury or in post-traumatic arthritis is one of the leading areas of orthopedic care. There are increasingly more patients with a history of maxillofacial or plastic surgery requiring articular cartilage repair. According to VADEMECUM, upwards of 21,000 rhinoplasties are performed in Russia every year. Articular cartilage injuries account for over $10 \%$ of all traumatic injuries; in most cases, the mandible is involved. One of the promising treatment options for injuries and defects of the ear and nose, including microtia, is chondrocyte implantation. Maxillofacial surgery is performed in different age groups, but, according to ISAPS (the International Society of Aesthetic Plastic Surgery), 65\% of rhinoplasties are performed on female patients aged 19 to 34 years. Synthetic implants 
used in reconstructive surgery cause delayed immunologic and inflammatory responses in 10-16\% of cases [3].

Some companies have already started testing their products for reconstructive surgery. The University Hospital of Basel (Switzerland) has launched a clinical trial (ClinicalTrials. gov ID: NCT01242618) of an engineered cartilage graft for nasal alar reconstruction in patients with non-melanoma skin cancer. The graft was derived from the autologous human nasal chondrocytes cultured on a porcine collagen I/III membrane. So far, the first phase involving 5 patients has been completed.

Most developers use multicomponent systems for creating autologous cartilages suitable for implantation. For example, chondrocytes expanded in the medium containing the basic fibroblast growth factor FGF-2 and BMP-2 preserve their chondrogenic potential and form a high-quality, properly sized cartilage. A study reports that chondrocytes expanded in the presence of FGF-2 and cultured in vitro in a 3D biodegradable scaffold (polyglycolic acid, PGA) for 6 weeks formed a cartilage which contained 3.7 times more chondrocytes than a cartilage grown without FGF-2; the weight of the construct was 4.2 times greater and its glycosaminoglycan content was 2.8 times higher. The cartilage formed by the chondrocytes cultured in the presence of the bone morphogenetic protein BMP-2 and passaged in a medium supplemented with FGF-2 contained 1.5 more glycosaminoglycans and was characterized by their more homogenous distribution than a similar cartilage grown without BMP-2 [4]. In order to obtain a cartilage graft of an appropriate size and optimal mechanical properties, chondrocytes need to be cultured for 2 weeks prior to implantation.

In another study, expanded human nasal septum chondrocytes obtained from 4 donors were seeded on a Hyaff-11 scaffold, cultured in vitro for 2 or 4 weeks and then subcutaneously transplanted into immunodeficient mice. Two weeks after implantation, the elasticity of the cartilage precultured in vitro was 2.7 times higher than the elasticity of the construct transplanted immediately after cell seeding [5]. Fetal bovine serum (FBS) used to culture human nasal septum chondrocytes can be replaced with autologous human blood serum. Histopathology, immunohistology and biochemical evaluation of cell proliferation, glycosaminoglycan and collagen II content did not reveal significant differences between chondrocytes cultured in the presence of different serum types [6]. Importantly, the use of autologous serum reduces cell culture costs and the dangers associated with FBS, including the risks of immunogenicity or contamination with undetected agents, like prions that cause spongiform encephalopathy.

Among the advantages of autologous cartilage grafts (i.e., grafts harvested from the same patient) are good longterm cartilage survival, availability and immunotolerance. The downsides include the risk of donor site morbidity and graft resorption over time. The most common complication is warping typically seen in costal cartilage grafts [7]. Cartilage grafts take different shapes, from rectangular to trapezoidal to oval. Their size ranges from $1-2 \mathrm{~mm}$ to a few square $\mathrm{cm}$. The graft is carved out of the harvested tissue samples and adjusted to a patient's parameters immediately during surgery. To achieve the desired curvature, small incisions can be made on the graft surface. It is possible to use articular cartilage grafts in 2 or more layers for improved strength. Grafts derived from the elastic ear cartilage can be folded to achieve better rigidity [8]. The optimal thickness of the graft is $1-1.5 \mathrm{~mm}$. Reconstruction of the nasal dorsum is done with $1 \mathrm{~mm} 3$ pieces of the cartilage wrapped in Surgicel, fascia lata or temporal fascia and modelled in the recipient bed prepared in advance. Unwrapped grafts can proliferate, accumulate collagen after transplantation [9] and tend to resorb. Wrapped grafts are reported to exhibit signs of pronounced inflammation on a histopathologic examination [10].

A bioengineered cartilage graft has a few advantages over a conventional autologous graft: it requires less donor tissue and can be grown to a large size. This is especially important when there is a need for a repeat or revision surgery but the donor site has been depleted [8] and other donor sites are not available [11]. Using cell-based technology for engineering a graft identical to the native cartilage obviates the need for harvesting large volumes of human tissue, reduces the number of surgical interventions (for example, microtia repair normally takes 2 to 5 interventions), improves the cosmetic outcome, and makes the entire procedure less laborious. A bioengineered cartilage is expected to mimic its native counterpart in shape, size and mechanical properties.

Osteoarthrosis $(\mathrm{OA})$ is the most common joint disorder affecting at least $20 \%$ of the world's population. Usually, the age of onset is above 40 years. Radiographic signs of $\mathrm{OA}$ are detected in $50 \%$ of people aged over 55 years and $80 \%$ of people aged over 75 years. OA of the knee joint (gonarthrosis) affects more women than men; by contrast, coxarthrosis (OA of the hip joint) is more prevalent in men than women [12]. According to the World Health Organization, OA of the knee and hip joints is the $11^{\text {th }}$ leading cause of disability, and the number of patients with $O A$ is continuously growing [13]. According to some estimates, OA of the knee joint accounts for $83 \%$ of all OA cases [14]. As the world's population is aging, the prevalence of $O A$ is increasing.

At present there are no effective noninvasive and minimally traumatic pathogenetic treatments for gonarthrosis. Most treatments available are derived from hyaluronic acid (prosthetic synovial fluid). After a few years of symptomatic therapy, most patients end up needing a knee joint replacement. According to Global data, 33,000 knee replacement surgeries were performed in 2017 Russia. Depending on the prosthesis model, revision surgery (i.e. replacement of worn-out components of the prosthesis) is normally performed 5 to 10 years after the initial surgery. The service life of the prosthesis is approximately 15 years. OA of the hip joint often leads to femoral head osteonecrosis, necessitating total hip replacement, which is not recommended for young patients. Total hip arthroplasty is a costly and traumatic procedure; about $40 \%$ of the operated patients need a revision surgery within 10 years after the initial intervention. Immobilization leads to high mortality within a year in unoperated patients.

Today, cell-based medicinal products for articular cartilage regeneration are an alternative to classic reconstructive surgery involving subchondral drilling and abrasive arthroplasty. Some of such treatments are already available on the market, while others are currently undergoing clinical trials. In 2017, the EU witnessed the launch of Spherox (CO.DON AG), spheroids derived from autologous chondrocytes. Spherox is suitable for treating recent injuries of the knee joint of less than $10 \mathrm{~cm}^{2}$ in size and has a few serious drawbacks: donor tissue is harvested arthroscopically, and another arthroscopy is needed for intraarticular implantation of the cultured spheroids. So far, the efficacy of Spherox for treating OA has not been demonstrated in comparative clinical studies. Other cell-based medicinal products available on the market are represented by allogenic and autologous derivatives of mesenchymal stem cells (MSC) isolated from adipose tissue or bone marrow, including Elixcyte by UnicoCell Biomed CO., Taiwan (culture-expanded allogenic adipose tissue MSC, phase 1-2 trial; Regenexx-SD by Regenerative Sciences, USA (non-cultured bone marrow 
cells); ReJoin by Cellular Biomedicine Group, USA (adiposederived mesenchymal stromal cells, phase 2 trial; RegStem by EMO Biomedicine Corporation, Taiwan (culture-expanded autologous mesenchymal stromal cells, phase 1 trial; JointStem by Nature Cell Co. Ltd., Korea (adipose-derived autologous mesenchymal stromal cells, phase 2 trial; StroMed by VivaTech International Inc., Netherlands (mechanically isolated stromal vascular fraction of adipose tissue, phase 2 trial). As a rule, these treatments are effective in very early stages of OA when its clinical manifestations are minimal or absent. This is due to the structural properties of the articular cartilage: cartilaginous tissue consists of the abundant extracellular matrix with few functional cells, i.e. chondrocytes that exhibit low plasticity and proliferative activity. This is why articular cartilages cannot heal spontaneously in physiological conditions.

\section{Key requirements for donor tissue and cell isolation protocols}

The source of a cartilage graft is the hyaline cartilage of the joint, the nasal septum, auricular or costal cartilage tissue. The transplant is expected to be easily removed should the need arise and not to irreversibly integrate into the surrounding tissue [3]. One of the main requirements for the graft is long-term size/ shape stability. It is essential that the transplanted cartilage should not expand or change its shape over time, forming visible defects ("bosses"). The transplant must be resistant to fibrosis and resorption. This can be achieved if the transplant is composed of only chondrocytes with low proliferation potential and is devoid of chondroblasts. At the same time, the histological structure of the resultant cartilage must mirror the structure of a mature cartilage.

To maintain the compositional stability of the transplant, cartilage tissue should be harvested without the perichondrium. However, the border between the cartilage and the perichondrium is indistinct, and the harvested sample will inevitably contain a few chondroblasts [15]. The cartilage is composed of 2 layers that are visibly distinct under the microscope. The superficial layer contains elongated fibroblast-like cells oriented parallel to the surface. This layer is relatively abundant with collagen I. The deep layer is constituted by round cells.

Thus, to isolate chondroblast for further expansion, the harvested piece of cartilage is subjected to brief enzymatic incubation resulting in the digestion of its superficial layer; the detached cells are used for further expansion. With this approach, there is no need to mince the cartilage. To obtain chondrocytes for further culture, cells isolated during enzymatic incubation are removed, the cartilage is minced and enzymatic incubation is then continued for a few hours following the technique described in [16] or a similar technique. Cell yield increases with a patient's age [17], which might be explained by the lower density of the extracellular matrix in older patients. The proportion of viable isolated cells is the same in all age groups. Cell monolayer cultures can be maintained through 4 passages [18], the number of cells doubling with each passage.

\section{Technologies for fabricating chondrocyte-based medicinal products}

The articular cartilage contains few cells (5-10\% of its volume) in comparison with the extracellular matrix. The area of a bioengineered cartilage must be comparable with the size of the tissue defect, as is the case with Co.don chondrospheres for the reconstruction of the knee joint cartilage. The thickness of the cartilage defect that can be repaired with the Co.don technology is similar to the thickness of the cartilage graft used in rhinoplasty $(1-1.5 \mathrm{~mm})$. This means there is a readyfor-use, well-established technique for cartilage size reduction and cultivation. Extrapolation of Co.don data shows that the approximately $40 \times 10^{6}$ chondrocytes are needed to create a graft for closing a $4 \mathrm{~cm}^{2}$ cartilage defect (50 chondrospheres per $1 \mathrm{~cm}^{2}$ of a knee joint defect; 200,000 cells per chondrosphere). Up to $1-1.5 \times 10^{6}$ cells can be obtained from $1 \mathrm{~g}$ of the harvested nasal septum cartilage [16]. In one of the studies, the nasal septum cartilage separated from the perichondrium was predigested with pronase or hyaluronidase and then finally digested with collagenase II. The optimal seeding density at which chondrocytes proliferate and remain viable for 10 days is $1 \times 10^{5}$ cells per culture flask.

On day 10 , cells isolated from the superficial layer of the nasal septum cartilage and cultured in agarose start to lose their spindle shape, become more oval and can be assessed by staining with safranin $O$. The ratio between collagen II and I expression increases as the cells mature in a culture medium that does not contain any growth-stimulating factors. Some authors believe that chondrogenic factors TGF $\beta$ and BMP are not essential for the successful differentiation of cells into chondrocytes [15]. However, other researchers think that these factors increase the chondrogenic potential of chondrocyte cultures [19].

The presence of autologous serum can stimulate chondrocyte proliferation [20]. Supplementing the medium with $50 \mathrm{ng} / \mathrm{ml}$ CCN2/CTGF (CCN family 2/connective tissue growth factor) can increase by one and a half times proliferation of rabbit auricular chondrocytes and proteoglycan synthesis by these cells, as compared to the cells cultured in a medium containing only $10 \%$ serum [21]. The low oxygen environment of a bioreactor accelerates chondrocyte differentiation. The best differentiation is achieved at 5\% DO (1\% oxygen in the liquid phase) [22]

The majority of the applied technologies offer a 2-step procedure for cartilage engineering: chondrocyte expansion in a monolayer culture (the cells are reseeded 14 or sometimes 6-8 days after initial seeding) and creation of a 3D construct. In a monolayer culture, chondrocytes dedifferentiate when their proliferation is stimulated. It is not advisable to passage chondrocytes more than 4 times due to poor differentiation and predisposition to apoptosis [23].

In the second step, which takes about 7 days, a 3D tissue construct is grown on a biocompatible fibrous polymer scaffold (PGA etc.) or in a scaffold-free system using gelling polymers (alginate, ARC technology). Researchers working with 3D matrices think that chondroblasts attached to the fibers of a 3D matrix more readily arrange into a 3D structure of an articular cartilage and better differentiate into mature chondrocytes [23] The ARC-technology facilitates maturation of fibroblast-like cells and promotes production of the extracellular matrix [24].

In another study, a porous HAp/ChS scaffold (collagen, hydroxyapatite and chondroitin sulfate) was used to engineer an ear cartilage [25]; such scaffold can assume the desired shape, and cells are distributed uniformly throughout its volume. In the cited study, the cells were cultured in a rotating bioreactor.

Importantly, as much as $75 \%$ if cells is lost during seeding into a scaffold. Given the proportions of cells and the extracellular matrix in a cartilage, the focus should be shifted from increasing the number of cells to stimulating extracellular matrix synthesis. So far, the biomechanical properties of bioengineered cartilage tissue are inferior to those of a native cartilage.

A group of researchers has proposed a technology for $3 \mathrm{D}$ chondrocyte culture that does not rely on biocompatible 
polymers. Using layered chondrocyte sheets, the researchers were able to obtain a construct that had characteristics comparable to those of a native auricular cartilage [26-28].

This technology has been tested for safety and is now used for cartilage repair in Japan; so far, over 100 patients have received this treatment.

Sometimes the protocol for cartilage engineering includes one more step: maturation of the cartilage in vivo in immunodeficient (nude) mice. Despite the advantages, the method has serious limitations preventing it from mass use: it is difficult to guarantee that the end product will not contain any traces of murine tissue. However, it is still possible to monitor the maturation of a transplant in the recipient's body (for example, in cases when an auricular cartilage graft is grown for microtia repair).

The step of cell expansion in culture, which follows cell isolation, can be skipped: harvested cells can be immediately seeded into a scaffold. A histological examination of bioengineered tissue grown in a PGA scaffold was conducted after 28 days of cell culture [29]. Using immunohistochemical analysis, collagen levels, DNA content, and sulfated glycosaminoglycans (sGAG, assessed by staining with toluidine blue) were measured. At passage 0 (the seeding of cells into a PGA scaffold right after harvesting), the growing cartilage was comparable with the cartilage tissue derived from precultured cells and had higher DNA and SGAG content. However, the amount of cells isolated from a human nasal septa and used for immediate seeding into a scaffold was insufficient to grow a properly sized cartilage.

Chondrocytes can arrange into a cartilage-like structure in the absence of a scaffold. However, they grow slowly. A study reports that cells seeded at the density of $1.6 \times 10^{6}$ chondrocytes per $1 \mathrm{~cm}^{2}$ and grown for 10 weeks generated a 291- $\mu$ m-thick construct; of that size, calcified tissue amounted to $77 \mu \mathrm{m}[30]$.

\section{Basic markers for quality control}

Cells cultured as a monolayer are elongated and have a chondroblast-like phenotype. If cells are cultured at high density in 3D scaffolds, they acquire a round shape and start to resemble chondrocytes. On day 7 of high-density culture in a 3D matrix, the cells become round, with large euchromatic nuclei, a few nucleoli and a well-structured cytoplasm. As early as day 1 of culture in a 3D fibrous matrix, numerous cell contacts can be detected. On the periphery, the cells look more spherical, but in the center they are flatter. On day 7 , cartilage nodules appear [23]. The immunohistochemical analysis showed that cell cultures derived from the nasal septum cartilage express collagen I and CD44, whereas expression of collagen I and aggrecan is significantly lower [16].

Chondrocytes isolated from human cartilaginous tissue express CD105, CD44 and CD73 and are negative for CD146. The receptor for hyaluronic acid CD44 is abundantly expressed in young tissue; as the cartilage becomes thicker CD44 expressions declines. Cartilaginous tissue was shown to express Sox-9 RNA (the gene is considered to be the marker of chondrogenesis). It also lacked expression of SBFA-1 RNA, the marker of ossification [15].

It is recommended to measure glycosaminoglycan (GAG) content instead of collagen levels in a growing $3 D$ construct to evaluate the amount of the extracellular matrix because GAGs are more abundant and their synthesis starts earlier than collagen synthesis. After 2 weeks of culture, GAG levels were $7 \mu \mathrm{g}$ per 40,000 seeded cells [31].
Chondrocyte differentiation can be assessed using commercial monoclonal antibodies [32]. Chondrocyte maturation can be assessed with surface markers expressed by mature and immature cells during culture. The expression of CD44 and integrin alpha-5 is considered the most specific for immature chondrocytes and chondroblasts [33]. It is also useful to measure collagen I and II, S100, aggrecan, sox 6, sox 9 [34], cartilage-expressed gene 1, or CRTAC 1 [35], and $\mathrm{Ca}^{2+}$ release-activated $\mathrm{Ca}^{2+}$ channel [36].

\section{Key characteristics of bioengineered tissue}

The biochemical composition of a cartilage in a 45 to 47 -year old human per $1 \mathrm{~g}$ cartilaginous tissue is as follows: 83-88 mg of collagen and 27-29 mg of sulfated glycosaminoglycans; the total amount of cells is 25-26 million [29].

Histologically, a healthy cartilage is composed of chondrocytes differing in shape and metabolic activity. The cells are more round in the center of the cartilage, as compared to its periphery. The cell to the extracellular matrix ratio declines from the periphery to the center. The cartilage lacks collagen 1 , but contains collagen 3 [37].

PoC studies of bioengineered tracheal cartilages derived from a nasal ovine cartilage analyzed the histological appearance of the resultant 3D products stained with hematoxylineosin and safranin O. Cartilaginous nodules were detected in the bioengineered tissue surrounded by the extracellular matrix. The primary biomechanical property of the cartilage is compressive stiffness; in the study, it ranged from 0.44 and $0.7 \mathrm{MPa}$ depending on orientation. During storage, this parameter increases by approximately $50 \%$ a month [38, 39]. In another study, the best compressive stiffness demonstrated by the samples was $0.0056 \mathrm{MPa}$, which is way inferior to the parameters of native cartilage tissue [40]. If the protocol for cartilage growth is adjusted to include cartilage maturation in $\mathrm{nu} / \mathrm{nu}$ mice, the resultant construct assessed after 30 days of culture has improved stiffness.

To study how well the bioengineered cartilage can recover its shape, $10 \times 2 \times 1 \mathrm{~mm}$ strips of a construct obtained with the ARC-technology (10 weeks of culture in a scaffold) were loaded into the controlled environment of a bending bioreactor where stress was applied to the samples using a $5 \mathrm{~mm}$ loading post. The angle between the margins of the strip was measured immediately after applying stress (Oh), $2 \mathrm{~h}$ and $24 \mathrm{~h}$ after unloading. In other words, shape retention was assessed ( $0 \%$ - complete recovery of shape, the opening angle is $\left.180^{\circ}\right)$. Differences in this parameter between the native cartilage and the bioengineered construct were insignificant [41]. Dynamic flexural stiffness (resistance to bending) of the construct was $0.014 \pm 0.019 \mathrm{~N} / \mathrm{mm}$ vs $0.19 \pm 0.15 \mathrm{~N} / \mathrm{mm}$ of the native tissue [42]; hydroxyproline content was similar between the bioengineered and native tissues.

The average GAG content in the construct produced with the ARC technology was $0.318 \mathrm{ng}$ per cell. The average collagen II content was $0.2 \mu \mathrm{g} / \mathrm{mg}$ wet tissue weight; collagen I content was very low. GAG content per $1 \mathrm{mg}$ wet tissue weight was $10.74 \mu \mathrm{g} / \mathrm{mg}$ before implantation into immunodeficient mice, $8.86 \mu \mathrm{g} / \mathrm{mg}$ after 30 days of in vivo culture and $2.73 \mu \mathrm{g} / \mathrm{mg}$ after 60 days of in vivo culture. Collagen II content was $0.02 \mu \mathrm{g} / \mathrm{mg}$ wet weight before implantation, $0.78 \mu \mathrm{g} / \mathrm{mg}$ after 30 days of in vivo culture and $1.44 \mu \mathrm{g} / \mathrm{mg}$ after 60 days of in vivo culture. Collagen I content was below the detection threshold, similarly to the native cartilage. The proportion of viable cells in the construct was above $90 \%$. Still, the mechanical properties of the construct were inferior to those of the native cartilage [40]. 


\section{CONCLUSION}

There is a need for new protocols that can improve the yield of cells suitable for culture from donor tissue. Culture protocols are expected to produce a construct that mimics native tissue in its morphology, molecular (expression of glycosaminoglycans, collagen II, aggrecan), physiological and mechanical properties. Although costly technologies are required to reduce the probability of cross-contamination when working with autologous tissue and such work poorly scalable, it is still possible to create a product with reduced immunogenicity, posing little risk for infection. Developing a technology for producing implants mimicking a hyaline cartilage that can rapidly restore the function of the cartilage, allow the patient to return to the usual level of physical activity and minimize treatment costs is a pressing concern [43].

It is advisable to use 3D culture technologies for creating a neocartilage construct either by building chondrocyte layers consecutively or by shaping 2D cell cultures into spheroids with subsequent maturation in vitro or by using a combination of these 2 methods. In this case, chondrocytes retain their mature differentiated state and produce the extracellular matrix. With such products, there is no need to use additional scaffolding, which requires more clinical trials, complicates the technology and increases costs.

\section{References}

1. Madeira C, Santhagunam A, Salqueiro JB, Cabral JM. Advanced cell therapies for articular cartilage regeneration. Trends Biotechnol. 2015; 33 (1): 35-42.

2. Atsuyuki I, Takashi I, A Hari Reddi. Human Stem Cells and Articular Cartilage Regeneration. Cells. 2012; 1 (4): 994-1009.

3. Romo T, Kwak ES. Nasal grafts and implants in revision rhinoplasty. Facial Plast Surg Clin North Am. 2006; 14 (4): 373-87.

4. Fulco I, Largo RD, Miot S, Wixmerten A, Martin I, Schaefer DJ, et al. Toward clinical application of tissue-engineered cartilage. Facial Plast Surg. 2013; 29 (2): 99-105.

5. Martin I, Suetterlin R, Baschong W, Heberer M, Vunjak-Novakovic G, Freed LE. Enhanced cartilage tissue engineering by sequentia exposure of chondrocytes to FGF-2 during 2D expansion and BMP-2 during 3D cultivation. J Cell Biochem. 2001; 83 (1): 121-8.

6. Farhadi J, Fulco I, Miot S, Wirz D, Haug M, Dickinson SC, et al. Precultivation of engineered human nasal cartilage enhances the mechanical properties relevant for use in facial reconstructive surgery. Ann Surg. 2006; 244 (6): 978-85.

7. Immerman S, White WM, Constantinides M. Cartilage grafting in nasal reconstruction. Facial Plast Surg Clin North Am. 2011; 19 (1): 175-82

8. Echeverry A, Carvajal J, Medina E. Alternative technique for tip support in secondary rhinoplasty. Aesthet Surg J. 2006; 26 (6): 662-8.

9. Yilmaz S, Erçöçen AR, Can Z, Yenidünya S, Edali N, Yormuk E. Viability of diced, crushed cartilage grafts and the effects of Surgicel (oxidized regenerated cellulose) on cartilage grafts. Plast Reconstr Surg. 2001; 108 (4): 1054-60.

10. Fatemi MJ, Hasani ME, Rahimian S, Bateni H, Pedram M, Mousavi SJ. Survival of block and fascial-wrapped diced cartilage grafts: an experimental study in rabbits. Ann Plast Surg. 2012; 69 (3): 326-30.

11. Yenigun A, Meric A, Verim A, Ozucer B, Yasar $H$, Ozkul MH. Septal perforation repair: mucosal regeneration technique. Eur Arch Otorhinolaryngol. 2012; 269 (12): 2505-10.

12. Galushko EA, Erdes SHF, Alekseeva LI. Osteoarthrosis in outpatient practice. Sovremennaya revmatologiya. 2012; 6 (4): 66-70. Russian.

13. Lohmander LS. Knee replacement for osteoarthritis: facts, hopes, and fears Medicographia. 2013; 35: 181-8

14. Vos T, et al. Global, regional, and national incidence, prevalence, and years lived with disability for 301 acute and chronic diseases and injuries in 188 countries, 1990-2013: a systematic analysis for the Global Burden of Disease Study 2013. Lancet. 2015; 386 (9995): 743-800.

15. Amaral RJ, Pedrosa Cda S, Kochem MC, Silva KR, Aniceto M, et al. Isolation of human nasoseptal chondrogenic cells: a promise for cartilage engineering. Stem Cell Res. 2012; 8 (2): 292-9.

16. Oseni AO, Butler PE, Seifalian AM. Optimization of chondrocyte isolation and characterization for large-scale cartilage tissue engineering. J Surg Res. 2013; 181 (1): 41-8.

17. Rotter N, Bonassar LJ, Tobias G, Lebl M, Roy AK, Vacanti CA. Age dependence of cellular properties of human septal cartilage: implications for tissue engineering. Arch Otolaryngol Head Neck
Surg. 2001; 127 (10): 1248-52.

18. Haisch A, Marzahn U, Mobasheri A, Schulze-Tanzil G, Shakibaei M. Development and phenotypic characterization of a high density in vitro model of auricular chondrocytes with applications in reconstructive plastic surgery. Histol Histopathol. 2006; 21 (5): 467-76.

19. Timur U, Caron M, Akker G, Windt A, Visser J, Rhijn L, et al. Increased TGF- $\beta$ and BMP levels and improved chondrocytespecific marker expression in vitro under cartilage-specific physiological osmolarity. Int J Mol Sci. 2019; 20 (4): 795

20. Tallheden T, Lee J, Brantsing C, Månsson JE, Sj-gren-Jansson E, Lindahl. A Human serum for culture of articular chondrocytes. Cell Transplant. 2005; 14 (7): 469-79.

21. Fujisawa $T$, Hattori $T$, Ono M, Uehara J, Kubota S, Kuboki T, et al. CCN family 2/connective tissue growth factor (CCN2/ CTGF) stimulates proliferation and differentiation of auricular chondrocytes. Osteoarthritis Cartilage. 2008; 16 (7): 787-95.

22. Malda J, Blitterswijk CA, Geffen M, Martens DE, Tramper J, Riesle J. Low oxygen tension stimulates the redifferentiation of dedifferentiated adult human nasal chondrocytes. Osteoarthritis Cartilage. 2004; 12 (4): 306-13.

23. Haisch A, Marzahn U, Mobasheri A, Schulze-Tanzil G, Shakibaei M. Development and phenotypic characterization of a high density in vitro model of auricular chondrocytes with applications in reconstructive plastic surgery. Histol Histopathol. 2006 May; 21 (5): 467-76.

24. Masuda K, Sah RL, Hejna MJ, Thonar EJ. A novel two-step method for the formation of tissue-engineered cartilage by mature bovine chondrocytes: the alginate-recovered-chondrocyte (ARC) method. J Orthop Res. 2003; 21 (1): 139-48.

25. Ohyabu Y, Adegawa T, Yoshioka T, Ikoma T, Shinozaki K, Uemura T, et al. A collagen sponge incorporating a hydroxyapatite/ chondroitinsulfate composite as a scaffold for cartilage tissue engineering. J Biomater Sci Polym. 2009; 20 (13): 1861-74.

26. Yanaga $\mathrm{H}$, et al. Clinical application of cultured autologous human auricular chondrocytes with autologous serum for craniofacial or nasal augmentation and repair. Plast Reconstr Surg. 2006; 117 2019-30.

27. Yanaga H. Imai K, Fujimoto T, Yanaga K. Generating ears from cultured autologous auricular chondrocytes by using two-stage implantation in treatment of microtia. Plast Reconstr Surg. 2009; 124: 817-25.

28. Yanaga H, Imai K, Yanaga K. Generative surgery of cultured autologous auricular chondrocytes for nasal augmentation. Aesthetic Plast Surg. 2009; 33: 795-802.

29. Homicz MR, Schumacher BL, Sah RL, Watson D. Effects of serial expansion of septal chondrocytes on tissue-engineered neocartilage composition. Otolaryngol Head Neck Surg. 2002; 127 (5): 398-408.

30. Yu H, Grynpas M, Kandel RA. Composition of cartilagenous tissue with mineralized and non-mineralized zones formed in vitro. Biomaterials. 1997; 18 (21): 1425-31.

31. Alexander TH, Sage AB, Chen AC, Schumacher BL, Shelton E, 
Masuda K, et al. Insulin-like growth factor-I and growth differentiation factor-5promote the formation of tissue-engineered human nasal septal cartilage. Tissue Eng Part C Methods. 2010; 16 (5): 1213-21.

32. Osch GJ, Veen SW, Marijnissen WJ, Verhaar JA. Monoclonal antibody 11-fibrau: a useful marker to characterize chondrocyte differentiation stage. Biochem Biophys Res Commun. 2001; 280 (3): 806-12.

33. Kobayashi S, Takebe T, Zheng YW, Mizuno M, Yabuki Y, Maegawa J, et al. Presence of cartilage stem/progenitor cells in adult mice auricular perichondrium. PLoS One. 2011; 6 (10): e26393.

34. Outani H, Okada M, Yamashita A, Nakagawa K, Yoshikawa H, Tsumaki N. Direct induction of chondrogenic cells from human dermal fibroblast culture by defined factors. PLoS One. 2013; 8 (10): e77365.

35. Crowe N, Swingler TE, Le LT, Barter MJ, Wheeler G, Pais H, et al. Detecting new microRNAs in human osteoarthritic chondrocytes identifies miR-3085 as a human, chondrocyte-selective, microRNA. Osteoarthritis Cartilage. 2016; 24 (3): 534-43.

36. Liu S, Takahashi M, Kiyoi T, Toyama K, Mogi M Genetic manipulation of calcium release-activated calcium channel 1 modulates the multipotency of human cartilage-derived mesenchymal stem cells. J Immunol Res. 2019; 2019: 7510214.

\section{Литература}

1. Madeira C, Santhagunam A, Salgueiro JB, Cabral JM. Advanced cell therapies for articular cartilage regeneration. Trends Biotechnol. 2015; 33 (1): 35-42.

2. Atsuyuki I, Takashi I, A Hari Reddi. Human Stem Cells and Articular Cartilage Regeneration. Cells. 2012; 1 (4): 994-1009.

3. Romo T, Kwak ES. Nasal grafts and implants in revision rhinoplasty. Facial Plast Surg Clin North Am. 2006; 14 (4): 373-87.

4. Fulco I, Largo RD, Miot S, Wixmerten A, Martin I, Schaefer DJ, et al. Toward clinical application of tissue-engineered cartilage. Facial Plast Surg. 2013; 29 (2): 99-105.

5. Martin I, Suetterlin R, Baschong W, Heberer M, Vunjak-Novakovic G, Freed LE. Enhanced cartilage tissue engineering by sequential exposure of chondrocytes to FGF-2 during 2D expansion and BMP-2 during 3D cultivation. J Cell Biochem. 2001; 83 (1): 121-8.

6. Farhadi J, Fulco I, Miot S, Wirz D, Haug M, Dickinson SC, et al. Precultivation of engineered human nasal cartilage enhances the mechanical properties relevant for use in facial reconstructive surgery. Ann Surg. 2006; 244 (6): 978-85.

7. Immerman S, White WM, Constantinides M. Cartilage grafting in nasal reconstruction. Facial Plast Surg Clin North Am. 2011; 19 (1): 175-82.

8. Echeverry A, Carvajal J, Medina E. Alternative technique for tip support in secondary rhinoplasty. Aesthet Surg J. 2006; 26 (6): 662-8.

9. Yilmaz S, Erçöçen AR, Can Z, Yenidünya S, Edali N, Yormuk E. Viability of diced, crushed cartilage grafts and the effects of Surgicel (oxidized regenerated cellulose) on cartilage grafts. Plast Reconstr Surg. 2001; 108 (4): 1054-60.

10. Fatemi MJ, Hasani ME, Rahimian S, Bateni H, Pedram M, Mousavi SJ. Survival of block and fascial-wrapped diced cartilage grafts: an experimental study in rabbits. Ann Plast Surg. 2012; 69 (3): 326-30.

11. Yenigun A, Meric A, Verim A, Ozucer B, Yasar $H$, Ozkul MH. Septal perforation repair: mucosal regeneration technique. Eur Arch Otorhinolaryngol. 2012; 269 (12): 2505-10

12. Галушко Е. А., Эрдес Ш. Ф., Алексеева Л. И. Остеоартроз в амбулаторной практике. Современная ревматология. 2012; 6 (4): 66-70.

13. Lohmander LS. Knee replacement for osteoarthritis: facts, hopes, and fears Medicographia. 2013; 35: 181-8

14. Vos T, et al. Global, regional, and national incidence, prevalence, and years lived with disability for 301 acute and chronic diseases and injuries in 188 countries, 1990-2013: a systematic analysis for the Global Burden of Disease Study 2013. Lancet. 2015; 386 (9995): 743-800.

15. Amaral RJ, Pedrosa Cda S, Kochem MC, Silva KR, Aniceto M, et al. Isolation of human nasoseptal chondrogenic cells: a promise
37. Popko M, Bleys RL, De Groot JW, Huizing EH. Histological structure of the nasal cartilages and their perichondrial envelope. I. The septal and lobular cartilage. Rhinology. 2007; 45 (2): 148-52.

38. Richmon JD, Sage A, Wong WV, Chen AC, Sah RL, Watson D. Compressive biomechanical properties of human nasal septal cartilage. Am J Rhinol. 2006; 20 (5): 496-501.

39. Glasgold MJ, Kato YP, Christiansen D, Hauge JA, Glasgold Al, Silver FH. Mechanical properties of septal cartilage homografts. Otolaryngol Head Neck Surg. 1988; 99 (4): 374-9.

40. Chang AA, Reuther MS, Briggs KK, Schumacher BL, Williams $\mathrm{GM}$, Corr M, et al. In vivo implantation of tissue-engineered human nasal septal neocartilage constructs: a pilot study. Otolaryngol Head Neck Surg. 2012; 146 (1): 46-52.

41. Reuther MS, Briggs KK, Neuman MK, Masuda K, Sah RL, Watson D. Shape fidelity of native and engineered human nasal septal cartilage. Otolaryngol Head Neck Surg. 2013; 148 (5): 753-7.

42. Caffrey JP, Kushnaryov AM, Reuther MS, Wong WW, Briggs KK, Masuda $K$, et al. Flexural properties of native and tissueengineered human septal cartilage. Otolaryngol Head Neck Surg. 2013; 148 (4): 576-81.

43. Zou J, Bai B, Yao Y. Progress of co-culture systems in cartilage regeneration. Expert Opin Biol Ther. 2018; 18 (11): 1151-8.

for cartilage engineering. Stem Cell Res. 2012; 8 (2): 292-9.

16. Oseni AO, Butler PE, Seifalian AM. Optimization of chondrocyte isolation and characterization for large-scale cartilage tissue engineering. J Surg Res. 2013; 181 (1): 41-8.

17. Rotter N, Bonassar LJ, Tobias G, Lebl M, Roy AK, Vacanti CA Age dependence of cellular properties of human septal cartilage: implications for tissue engineering. Arch Otolaryngol Head Neck Surg. 2001; 127 (10): 1248-52.

18. Haisch A, Marzahn U, Mobasheri A, Schulze-Tanzil G, Shakibaei M. Development and phenotypic characterization of a high density in vitro model of auricular chondrocytes with applications in reconstructive plastic surgery. Histol Histopathol. 2006; 21 (5): 467-76.

19. Timur U, Caron M, Akker G, Windt A, Visser J, Rhijn L, et al. Increased TGF- $\beta$ and BMP levels and improved chondrocytespecific marker expression in vitro under cartilage-specific physiological osmolarity. Int J Mol Sci. 2019; 20 (4): 795.

20. Tallheden T, Lee J, Brantsing C, Månsson JE, Si-gren-Jansson E, Lindahl. A Human serum for culture of articular chondrocytes. Cell Transplant. 2005; 14 (7): 469-79.

21. Fujisawa $T$, Hattori $T$, Ono $M$, Uehara J, Kubota S, Kuboki T, et al. CCN family 2/connective tissue growth factor (CCN2/ CTGF) stimulates proliferation and differentiation of auricular chondrocytes. Osteoarthritis Cartilage. 2008; 16 (7): 787-95.

22. Malda J, Blitterswijk CA, Geffen M, Martens DE, Tramper J, Riesle J. Low oxygen tension stimulates the redifferentiation of dedifferentiated adult human nasal chondrocytes. Osteoarthritis Cartilage. 2004; 12 (4): 306-13.

23. Haisch A, Marzahn U, Mobasheri A, Schulze-Tanzil G, Shakibaei M Development and phenotypic characterization of a high density in vitro model of auricular chondrocytes with applications in reconstructive plastic surgery. Histol Histopathol. 2006 May; 21 (5): 467-76.

24. Masuda K, Sah RL, Hejna MJ, Thonar EJ. A novel two-step method for the formation of tissue-engineered cartilage by mature bovine chondrocytes: the alginate-recovered-chondrocyte (ARC) method. J Orthop Res. 2003; 21 (1): 139-48.

25. Ohyabu Y, Adegawa T, Yoshioka T, Ikoma T, Shinozaki K, Uemura T, et al. A collagen sponge incorporating a hydroxyapatite/ chondroitinsulfate composite as a scaffold for cartilage tissue engineering. J Biomater Sci Polym. 2009; 20 (13): 1861-74.

26. Yanaga $\mathrm{H}$, et al. Clinical application of cultured autologous human auricular chondrocytes with autologous serum for craniofacial or nasal augmentation and repair. Plast Reconstr Surg. 2006; 117 2019-30.

27. Yanaga H, Imai K, Fujimoto T, Yanaga K. Generating ears from 


\section{REVIEW I CELL BIOLOGY}

cultured autologous auricular chondrocytes by using two-stage implantation in treatment of microtia. Plast Reconstr Surg. 2009; 124: 817-25

28. Yanaga H, Imai K, Yanaga K. Generative surgery of cultured autologous auricular chondrocytes for nasal augmentation. Aesthetic Plast Surg. 2009; 33: 795-802.

29. Homicz MR, Schumacher BL, Sah RL, Watson D. Effects of serial expansion of septal chondrocytes on tissue-engineered neocartilage composition. Otolaryngol Head Neck Surg. 2002; 127 (5): 398-408.

30. Yu H, Grynpas M, Kandel RA. Composition of cartilagenous tissue with mineralized and non-mineralized zones formed in vitro. Biomaterials. 1997; 18 (21): 1425-31.

31. Alexander TH, Sage AB, Chen AC, Schumacher BL, Shelton E, Masuda K, et al. Insulin-like growth factor-l and growth differentiation factor-5promote the formation of tissue-engineered human nasal septal cartilage. Tissue Eng Part C Methods. 2010; 16 (5): 1213-21.

32. Osch GJ, Veen SW, Marijnissen WJ, Verhaar JA. Monoclonal antibody 11-fibrau: a useful marker to characterize chondrocyte differentiation stage. Biochem Biophys Res Commun. 2001; 280 (3): 806-12.

33. Kobayashi S, Takebe T, Zheng YW, Mizuno M, Yabuki Y, Maegawa J, et al. Presence of cartilage stem/progenitor cells in adult mice auricular perichondrium. PLoS One. 2011; 6 (10): e26393.

34. Outani H, Okada M, Yamashita A, Nakagawa K, Yoshikawa H, Tsumaki N. Direct induction of chondrogenic cells from human dermal fibroblast culture by defined factors. PLoS One. 2013; 8 (10): e77365.

35. Crowe N, Swingler TE, Le LT, Barter MJ, Wheeler G, Pais H, et al.
Detecting new microRNAs in human osteoarthritic chondrocytes identifies miR-3085 as a human, chondrocyte-selective, microRNA. Osteoarthritis Cartilage. 2016; 24 (3): 534-43.

36. Liu S, Takahashi M, Kiyoi T, Toyama K, Mogi M Genetic manipulation of calcium release-activated calcium channel 1 modulates the multipotency of human cartilage-derived mesenchymal stem cells. J Immunol Res. 2019; 2019: 7510214.

37. Popko M, Bleys RL, De Groot JW, Huizing EH. Histological structure of the nasal cartilages and their perichondrial envelope. I. The septal and lobular cartilage. Rhinology. 2007; 45 (2): 148-52.

38. Richmon JD, Sage A, Wong WV, Chen AC, Sah RL, Watson D. Compressive biomechanical properties of human nasal septal cartilage. Am J Rhinol. 2006; 20 (5): 496-501.

39. Glasgold MJ, Kato YP, Christiansen D, Hauge JA, Glasgold Al, Silver FH. Mechanical properties of septal cartilage homografts. Otolaryngol Head Neck Surg. 1988; 99 (4): 374-9.

40. Chang AA, Reuther MS, Briggs KK, Schumacher BL, Williams $\mathrm{GM}$, Corr M, et al. In vivo implantation of tissue-engineered human nasal septal neocartilage constructs: a pilot study. Otolaryngo Head Neck Surg. 2012; 146 (1): 46-52.

41. Reuther MS, Briggs KK, Neuman MK, Masuda K, Sah RL, Watson D. Shape fidelity of native and engineered human nasal septal cartilage. Otolaryngol Head Neck Surg. 2013; 148 (5): 753-7.

42. Caffrey JP, Kushnaryov AM, Reuther MS, Wong WW, Briggs KK Masuda $\mathrm{K}$, et al. Flexural properties of native and tissueengineered human septal cartilage. Otolaryngol Head Neck Surg. 2013; 148 (4): 576-81.

43. Zou J, Bai B, Yao Y. Progress of co-culture systems in cartilage regeneration. Expert Opin Biol Ther. 2018; 18 (11): 1151-8. 